\title{
Positive Psychology in Novel "Merindu Baginda Nabi" According to Martin E.P. Seligman Perspective
}

\author{
Narita Dewi Cahyani ${ }^{1}$, Arief Rahman Hakim $^{2}$, Surotun Siqoyah ${ }^{3}$ \\ 1,2,3Universitas Islam Negeri Maulana Malik Ibrahim, Jalan Gajayana No 50 Malang, \\ Indonesia \\ \{dewinarita@gmail.com¹, ariefrhrahmab@gmail.com², surotunsiqoyah07@gmail.com³\}
}

\begin{abstract}
Most of people cannot recognize a means of positive psychology. Positive psychology is a study of psychology which examines humans from the positive side. The purpose of this study aims to describe the background of Rifa and mention the positive values on novel entitled "Merindu Baginda Nabi" which is found in Rifa itself according to positive psychology on Seligman persperctive. The researchers used qualitative descriptive methodology to analyze the novel. The results of this novel analysis consist of the description of Rifa's background and mention the positive values which found in Rifa itself those are; optimist, surrender, and greatful to God.
\end{abstract}

Keywords: Martin E.P. Seligman, positive emotions, positive values, positive psychology

\section{INTRODUCTION}

Nowadays people goal to be happy. According most of people, happy refers to wander wealth, become a successful entrepreneur, famous, being a boss, and so on. Those things create happiness and make them happy. Otherwise, happiness comes from human itself not from the things which mentions before. When people cannot reach their happiness, it can cause depression, frustration, stress and so on. In other hand, happiness can come from human beings itself such as; feeling grateful, surrender, optimistic and so on. So, that by giving thanks for all the blessings which is given by God for us can bring satisfaction for human and create happiness.

A figure in psychology, Martin Seligman, tried to spearhead a new study in psychology, which named positive psychology. Etymologically, Psychology means a branch of science which studies the human soul. Psychological studies more often discuss mental illness, cause of failure, stress, depression, etc. The study of psychology seems like a study of negative symptoms in humans. Even though every human being has positive and negative sides, Seligman's positive psychology is more focused on the positive side of humans [1, p. 360]. The topics of positive psychology studies are happiness, positive emotions, thankfulness, forgiveness, joy, wisdom, and love [2, p. xiv].

Positive psychology is a scientific studied since 1998. This study grew and developed well because of its widespread influence on humans. Positive psychology not only affects psychology but also in other fields such as business, politics, law, military, health and other fields. In a health field, the most prominent positive psychological effects are reduced mortality, a history of heart disease, stress, and depression. In conclusion, positive psychology is able to make people think healthier in order to make them more creative and productive [2, p. 1]. 
Positive pychology according to Seligman and Csikszentmihalyi defines as a scientific study of the positive function of humans which develops on several levels that consist of biology, personal, relational, institutional, cultural, and global dimensions of life. The aim of positive psychology itself is to provide knowledge about create meaningful life which makes each individual able to socialize and provide mutualism to other individuals [3, p. 121]. The main feature of positive psychology based on science that has been tested first so that each statement can be accounted for. The central position character determines the happiness or unhappiness of each individual and has a central concept of authentic happiness [2, p. 9].

Positive emotions are one of the topics of positive psychology studies. Positive emotions greatly influence the character of every human being. In the opposite side, positive emotions are very important for humans. Some researchers conducted research on positive emotions which can make one's life better. In evidence, a research results in positive emotions field can make someone healthier, more creative and become a more personable person. Thus, positive emotions have a very concrete influence in the fields of health, social, work, and personal [4, pp. 31-32].

Novel "Merindu Baginda Nabi" explains Rifa's character who is adopted by Mr. Nur and Mrs. Sal. Rifa lives and raises in a very religious and positive environment. In this novel, the researchers find many positive attitudes of Rifa figures such as optimism, humility, forgiveness, being kind to God, being grateful and always surrender to the good and bad destiny that God gave. Researchers are interested in looking deeper into the positive character in Rifa's characters based on Seligman's positive psychological perspective. The main focus of positive psychology studies is goodness and strength to create happiness.

Psycho Idea Journal written by Dian Yudhawati who is one of the students of Yogyakarta University at Psychology Faculty in 2018 entitled Positive Psychology Implementation in Student Personality Development. The results of this study are to implement positive psychology which is expected to shape students who can develop side positive in theirselves, developing positive emotions in social relations with others, positive thinking in overcoming various problems faced, having a positive attitude in learning from mistakes and finally being able to integrate all personality development course material in accordance with the hard skills obtained from each the department he is interested in [5, p. 111].

A journal of cultural literary directions written by Abdul Basid, Hasan Basri, Imroatul Ngarifah and Muh. Zuhdy Hamzah in 2018 entitled Happiness Authenticity in Novel Putra Salju (2011) by Salman El-Bahry: Literary Psychology Study. The purposes of this study are to understand the form of happiness authenticity in Salman El-Bahry's Putra Salju (2011) novel based on a psychological perspective and the other purpose was to reveal the human way to achieve the authenticity of happiness. However, the results of this study indicate that there are three forms of happiness authenticity in human life, namely a pleasant life, a good life, and meaningful life [6, p. 123] .

The community empowerment journal is written by Bonar Hutapea and Yohanes Budiarto in 2016 entitled Positive Psychology Application to Improve Wellbeing of Bruderan Teachers in Purwekerto. The results of this study were psycamp training was very effective in increasing the wellbeing of the teachers. In addition, Psycamp's effective contribution to Wellbeing is 33\%, while the majority thought to be influenced by a number of other factors which have not been involved in its workshop. The results of this training have both theoretical and practical implications [7, p. 25].

The purpose of this study is to describe the background of Rifa's figure and to mention the positive values that exist in the Rifa mentioned in the novel Merindu Baginda Nabi. The 
researchers will analyze the novel "Merindu Baginda Nabi" by Habiburrahman El-Shirazy according to the Seligman positive psychology perspective.

\section{METHODOLOGY}

This type of research used descriptive qualitative methodology, as suggested by Cresswell that qualitative research is an approach that is used to understand and know a phenomenon widely $[8$, p. 7$]$. Then the data sources used are primary data, namely the novel "Merindu Baginda Nabi" and secondary data are form books, journals, and articles that are related to the positive psychological perspective of Seligman.

The data collection is taken by reading and taking a note. The researchers use the reading technique to read and analyze the contents of the novel and taking note is used by the researchers to record the data which obtained from the reading technique [9, pp. 167-168]. The interactive analysis is used to analyze the data. It is model of Miles and Huberman, namely: the stages of data collection, data reduction, presentation of the data and drawing conclusions [10, pp. 147$151]$.

\section{FINDINGS AND DISCUSSION}

Table 1. Background of Rifa's Figure.

\begin{tabular}{ll}
\hline Form & Finding \\
\hline Religious & Close to the creator can make people \\
& feeling afraid to do negative things, so \\
& that they will be encouraged to always do \\
& positive things
\end{tabular}

\section{Background of Rifa's figure}

Rifa's life story begins when her biological mother abandon her in a garbage by herself. The baby kept crying until her voice was heard by an old grandmother who was going to the market in the early morning. It was the old grandmother who saved her before heavy rains occurred. During the care of the grandmother, the baby only drank rice water, because grandmother was unable to buy the baby milk every time. Finally after a few months of living with the grandmother, a husband and his wife wished to make Rifa becomes their adopted children, because since their marriage eight years ago they had not been blessed with a child. They really hope that grandma gives the baby to take care as their child. Finally, the grandmother gave the baby to the husband and wife hardly.

Now Rifa lives with her two adoptive parents named Mr. Nur and Mrs. Salamah. Rifa has been brought up lovingly in a very religious environment (close to the creator). When humans are close to the creator, they will feel afraid to do negative things. Then humans will be encouraged to always do positive things. There is no need to be surprised if the Rifa character in this novel grows into a teenager who is positive and religious.

"Dear Rifa, fear Allah, wherever you are. And remember, you should not embarrass the Prophet" [11, p. 11].

Taqwa is an absorption language from Arabic that gives rise to feelings of love or fear of Allah. According to Abu Dharr ra said that the Messenger of Allah (peace be upon him) said 
"have taqwa (truth) wherever you are, and follow bad deeds with good one, because this will erase it. Also dealing with people who show good behavior "[Sunan at-Tirmidzi] [12, p. 22]. There is a relation between the message delivered by Abah to Rifa with the hadith conveyed by Abu Dharr, namely the command to fear Allah wherever they are. In this novel Rifa is proven to be successful with her message which is proven by Rifa's positive character. In the study of positive psychology, a discussion of humans close to their Lord will present a sense of happiness that can prove by devotion to God. Thus, humans are able to provide positive behavior that will reveal what happened and that human will be happy.

Table 2. Positive Values in Rifa's Figures.

\begin{tabular}{ll}
\hline Form & Finding \\
\hline Optimist & Rifa act more confident and always \\
& confident in what she does \\
Surrender & Rifa not afraid to be hated by Arum or \\
& Tiwik, because she believes when she \\
& surrenders all her affairs to Allah then \\
& there is no need to worry about things \\
& beyond that. \\
Greatful to God & Although given a very difficult ordeal, \\
& Rifa was always patient and grateful \\
& for all the blessings God gave
\end{tabular}

Positive Values in Rifa's figures

At Rifa's school, she had a very hateful rival named Arum. Everything that she done will always wrong in Arum's opinion. That afternoon, when Arum went home from school, Rifa ventured to invite Arum to chat for a while but Arum did not respond. She even ignored and pretended not to hear Rifa's words. She turned on the engine of her car and left Rifa. Seeing the incident Rifa's friends came to her.

"Rif just ignored, assuming there was nothing. People don't have such thoughts and hearts for what to pay attention to. You are already too good Rif, "Ika fiercely.

"so do I. Especially if you read the status. Very close to you. I want to tear his mouth. Beautiful but evil! "Lina said.

"Never mind, I'll try my last attempt."

"What is that?", Asked Lina.

"I will go to his house and ask for an explanation. If I really have something wrong with her, I will apologize. "

"It's no use. You will be treated to a fierce dog, curse you!" "I'll still try. The last effort to connect with a friend. If she still does not want to, then what else " [11, p. 75].

The sentence that has been underlined by the researchers shows that one of the positive emotions which exists in Rifa is optimism. Optimist in KBBI refers someone who always positive in dealing with everything. Optimism is very important in life. Optimism will lead someone to always think positively in everything will create a meaningful life. Rifa's optimistic nature makes her act more confident and always confident in what she does. 
In other fields, such as businessman, a salesman who has an optimistic attitude will make him more enthusiastic and not easily discouraged from continuing in offering item which sold from one person to another or from one door to another. In sum, optimistic is very important for every human being to make more enthusiastic in making his life more meaningful so that he will end happily [13, p. 87].

After an accident Rifa's broke her left leg. She finally didn't go to school for several weeks. The doctor estimated that Rifa will be able to walk back to normal after six months of treatment. During his recovery period, her father forbade her to carry out activities as usual, but because the National Examination was about to be implemented, she finally ventured to permit her father to be allowed to attend school. With a heavy heart, Mr. Nur allowed her to attend school.

All the students at 33 high school national welcomed Rifa well except Arum. The beautiful girl really didn't care about the situation. Now she didn't care about Arum who really hates her so much. As long as what she did didn't hurt other people, she didn't pay attention. She tried to respect Arum as her friend and she also never wanted to avenge Arum's treatment of her. One day her mother advised her.

"This world contains not only good people, there are people who are bad. So to be a good or bad people are choices. Be a good person. If the person do bad thing to you, just leave it alone, you don't have to reply. The important thing is you are not naughty and misbehaving to others. If you are being bullied by someone, just leave it, you don't have to reply. The important thing is you are not evil and do not harm others. If you are slandered by someone, just leave it, you don't have to reply. The important thing is you don't slander others. If you do good deeds but are not considered by others, just leave it alone, don't think about it. Because Allah is all righteous [11, p. 86].

That advice is what she used to remember. When she found a friend who hate her so much like Arum, she won't hate her again. Even though Tiwik often slandered her to Arum, she also would not retaliate, she believed in God. There are many positive values which can get from the advise. They are surrender to God, not replying to the ugliness of others and not demanding that their kindness be appreciated by others. One of the most important traits is surrender to God.

If someone surrendered then there will be no more anxiety in that person because anxiety is a response that does not have clarity originating from someone's internal [14, p. 172]. Anxiety will be present in someone when he is not sure of his own abilities. In Islam, we are encouraged to always surrender to Allah. Surrender to everything that God has given or will give us is able to make our life happier. Feeling anxiety will not dwell in the life of someone who is always resigned to the fate of his God.

"If God is with you. So what you worry about" [11, p. 86].

The sentence above is continuing advice from Mrs. Sal for Rifa. It can be concluded that if everything is done has been given to God, there is no need to worry and fear anything. As in the novel nature of resignation makes Rifa not afraid to be hated by Arum or Tiwik, because she believes in Allah when she surrenders.

The problem that Rifa faced came in turns. After her left leg was broken due to being hit by a trail bike a few months ago it still cannot be said to be fully cured. She found a bigger problem, namely the loss of the figure of the man she loved. After her father passed away, Rifa became an orphanage volunteer in West Malang. One day she was asked to motivate the Jamboree 
participants. She told of the seven orphans who were so great. They were the Prophet, the Imam Syafii, Sheikh Abdul Qodir Jilani, Sheikh Said an-Nursi and so on. Rifa explained that even though being an orphan would not be a barrier for someone to become a successful human being. Hearing the stories Rifa conveyed, the faces of the orphans seemed to sparkle happily.

After the event was over, Rifa was escorted by Dian to go home. During on the way, she was crashed by a car which was driving so fast and caused Dian passed away immediately. Only Rifa was able to be saved, now she was totally paralyzed from the waist to the bottom. Mrs. Sal was really sad about his daughter's condition. Every Mrs. Sal saw Rifa's condition she always shed tears. She really can't bear to see her only child crippled at such a young age.

"Rifa can still be blessed with both hands that can write, oral that can speak, both eyes that can read the Qur'an, yo do not need to be sad mom" [11, p. 167].

Rifa's expression above shows how patient Rifa was even though she had been given such a difficult problem in her life. She also remaines grateful without the slightest complaint. Rifa's attitude of gratitude is one of the studies of positive psychological theory. Grateful means a feeling of gratitude to God. Gratitude for all the blessings God has given to humans will make human life more meaningful and with the meaningfulness of life that will bring happiness to every human being [15, p. 185]. For someone who is grateful for every problem that is given little meaning compared to the blessings that Allah has given to humans. Therefore, the nature of gratitude must always be there for every human being because thankfully it will bring a real happiness to human life.

\section{CONCLUSIONS}

According to the analysis of the novel "Merindu Baginda Nabi" in the perspective of Seligman positive psychology concludes that overall the novel teaches positive sentences through Rifa's character. A positive character shows optimistic, submissive and grateful for all things God has given or humans has given to us. These positive emotions are brought about by Rifa's character in the novel, which is the positive character that makes Rifa always behave positively in her daily life. Practically, the novel is very well read as a builder of positive characters especially for teenagers who searchs their identity. The storyline and characterization of Rifa in this novel are able to provide inspirations and insight in society they need to equip themselves with optimism in trying, fear in facing problems and gratitude for what is obtained.

\section{References}

[1] Jusmiati, „Konsep Kebahagiaan Martin Seligman: Sebuah Penelitian Awal,“ Rausyan Fikr, p. 360, 2017.

[2] I. S. Arif, Psikologi Positif: Pendekatan Saintifik Menuju Kebahagiaan, Jakarta: PT Gramedia Pustaka Utama, 2016.

[3] F. Aulia, „Aplikasi Psikologi Positif dalam Konteks Sekolah,“ Seminar Psikologi \& Kemanusiaan, p. 121, 2015.

[4] r. Biswas-Diener, Invitation to Positive Psychology: Research and Tools for the Professional a 6-week Course, Inggris: United Kingdom, 2008.

[5] D. Yudhawati, „Implementasi Psikologi Positif dalam Pengembangan Kepribadian Mahasiswa," Psycho Idea, p. 111, 2018. 
[6] A. B. \&. H. B. \&. I. N. \&. M. Z. Hamzah, „Autentisitas Kebahagiaan dalam Novel Putra Salj (2011) Karya Salman El-Bahry: Kajian Psikologi Sastra, “ Haluan Sastra Budaya, p. 123, 2018.

[7] B. H. \&. Y. Budiarto, „Aplikasi Psikologi Positif Untuk meningkatkan Wellbeing Guruguru Bruden Purwokerto,“" Jurnal Pemberdayaan Masyarakat, p. 25, 2016.

[8] C. Semiawan, Metode Penelitian Kualitatif, Jakarta: Grasindo, 2010.

[9] Kaelan, Metode Penelitian Kualitatif Interdisipliner Bidang Sosial, Budaya, Filsafat, Seni, Agama dan Humaniora, Yogyakarta: Paradigma, 2012.

[10] M. Idrus, Metode Penelitian Ilmu Sosial, Yogyakarta: Penerbit Erlangga, 2009.

[11] H. El-Shirazy, Merindu Baginda Nabi, Jakarta: Republika, 2018.

[12] A. G. \&. T. G. \&. H. Abiva, The Wisdom of Our Prophet SAW, Cina: Iqra' International Educational Foundation, 2011.

[13] A. Carr, Positive Psichology The Science of Happiness and Human Strengths, New York: Brunner-Routledge, 2004.

[14] G. M. \&. D. D. Emmanuel, How You Feel Is Up to You, The Power of Emotional Choice, Rahasia kekuatan Pilihan Emosional, Jakarta: PT Gramedia, 1994.

[15] T. W. GH.W., Menghadapi Stress dan Depresi, Seni Menikmati Hidup Agar Selalu Bahagia, Tugu Publisher, 2009.

[16] Subandi, „Sabar: Sebuah Konsep Psikologi,“ Jurnal Psikologi, p. 215, 2011. 